\title{
LINTASAN SEJARAH PERDAGANGAN PEREMPUAN DI INDONESIA
}

Oleh: Budiarti

Dosen Jurusan Sejarah FIS UNJ

\begin{abstract}
Abstaksi
Praktek perdagangan perempuan dan anak di Indonesia sudak dilakukan dalam kurun waktu yang cukup lama dengan berbagai modus seperti penghadiahan putri raja kepada kerajaan yang ditaklukkan. Kemudian kedatangan bangsa Belanda pada abad ke-16, perdagangan perempuan dilaukan secara transparan baik perempuan yang didatangkan dari Eropa, Asia, ataupun pribumi. Pembukaan perkebunan di Sumatra secara besar-besaran sebenarnya menjadi tempat praktek perdagangan perempuan. Banyak kaum perempuan dikirim ke tempat perkebunan tersebut, dan kebanyakan dijadikan pelacur. Di era global perempuan dijadikan ladang bisnis dengan berbagai modus, dari kawin kontrak sampai terlibat dalam perdagangan narkoba.
\end{abstract}

Praktek perdagangan perempuan dan anak di Indonesia sudah dilakukan dalam kurun waktu yang cukup lama. Praktek dimulai dari masa kerajaankerajaan yang ada di nusantara dengan modus operandi perkawinan politik Pada masa kerajaan, di Nusantara sudah menjadi kelaziman para putri raja dihadiahkan sebagai selir ataupun istri sebagai tanda takluk . (Dara Petak dan adik perempuannya dihadiahkan kepada Raja Majapahit Raden Wijaya sebagai tanda takluk kerajaan Melayu, Putri Cina yang dihadiahkan untuk kerajaan Cirebon ) Status sebagai istri raja atau selir yang hidup dalam lingkungan istana dengan kehidupan cukup mewah, namun tidak merubah status mereka tetap sebagai hadiah atau upeti. Dalam kehidupan di dalam istana para istri taklukan ini tidak punya kewenangan apa pun. Sejarah tidak mengungkapkan apakah diantara para putri tersebut ada yang melakukan perlawanan atau tidak dengan kondisi mereka.

Secara terang-terang perdagangan perempuan di Indonesia terjadi pada masa kolonial Belanda menguasai Indonesia. Bangsa Belanda datang pertamakali ke nusantara pada tahun 1596 berlabuh dipantai utara pulau Jawa dibawah pimpinan Cornelis De Houtman , selama 6 tahun kemudian makin banyak para pelaut Belanda yang berdatangan untuk menemukan sendiri dan kemudian menjual rempah-rempah yang sangat diperlukan untuk masyarakat Eropa seperti, lada, pala dan cengkeh, para pedagang Belanda ini memperoleh laba yang sangat besar sehingga seringkali timbul persaingan antar mereka. Sadar akan kerugian yang akan mereka alami jika mereka tidak bersatu maka tahun 1602 para pedagang ini kemudian mendirikan 
serikat dagang yang bernama VOC (Verenigde Oostindische Compagnie) Satu dewan direksi yang terdiri dari tujuh belas orang yang mewakili enam kamar dagang diwilayah Belanda . Mereka diberi kewenangan untuk mengambil keputusan dan menetapkan garis kebijakan VOC. Dalam kewenangannya VOC mempekerjakan pegawai sipil dan militer. Pegawai sipil dan militer ini didatangkan dari Belanda atau negara-negara Eropa. Mayoritas bangsa Belanda dan Eropa yang ada di nusantara adalah bujangan laki-laki, para pedatang bujangan ini dikenal suka mabuk-mabukan, membuat gaduh dan mengadakan hubungan dengan para perempuan pribumi. Kwatir akan merugikan VOC maka pimpinan VOC kemudian mendatang para perempuan Belanda ke nusantara dengan biaya VOC, namun kegiatan tersebut dihentikan pada tahun 1632. VOC bahkan kemudian mendukung hubungan antara laki-laki Belanda dengan para perempuan Asia, dengan tujuan untuk membentuk komunitas warga Belanda yang menetap dan bertahan di kepulauan nusantara . VOC kemudian membeli para budak perempuan Asia untuk dijadikan istri oleh pria Belanda,dengan syarat perempuan yang akan dinikahi harus beragama nasrani, tentu saja hal ini menjadi halangan oleh sebab itu kemudian karena tidak dapat menikah secara resmi maka banyak para laki-laki ini yang kemudian mempunyai nyai atau gundik. Para nyai atau gundik ini umumnya berasal dari para budak perempuan yang pada umumnya datang dari kalangan masyarakat miskin, dan status budak itu kemudian membuat mereka tidak mempunyai posisi merdeka, bisa saja seorang perempuan diperjualbelikan oleh pemiliknya apabila mereka tidak lagi meyukainya. Golongan serdadu ,kelasi merupakan golongan yang seringsekali memperlakukan budak -budak tersebut sebagai barang yang bisa diperjual belikan semau mereka.Jika kebetulan budak perempuan tersebut jatuh ketangan para petinggi Belanda mungkin nasibnya lebih baik.

Sebenarnya ada aturan bahwa laki-laki Belanda dilarang menikah tanpa izin atasannya; atau boleh menikah dengan budak tetapi harus membayar dahulu kepada VOC. Aturan ini mengesankan bahwa para budak ini adalah milik VOC yang bisa diperjualbelikan. Dengan aturan ini banyak para opsir, pegawai VOC yang melaksanakan perkawinan dengan para budak. Sedangkan untuk pejabat tinggi dan pedagang, ketentuan tersebut tidak berlaku. Pada tahun 1816 pemerintah Belanda menghapuskan peraturan ini. Namun status perempuan pribumi yang menikah dengan laki-laki Eropa tetap sama sebagai selir atau gundik. Selir dan gundik dalam kehidupan masyarakat pada waktu itu populer dengan istilah Nyai.

Bagaimana kehidupan para Nyai tersebut? Diceritakan dengan apik oleh G. Francis dalam buku Nyai Dasima, dan buku Bumi Manusia karangan Pramoedya Ananta Toer dengan pandangan yang berbeda (Kantrin Bandel 2006 ). Tugas seorang Nyai menjadi pengurus rumahtangga yang bergerak antar batas pembantu, ibu rumah tangga, istri dan pelacur (Capt. R.P Suyono 2005 ). Dengan batasan ini ada kecenderungan posisi perempuan menjadi sangat tidak jelas, sementara sang tuan bisa berbuat semaunya. Sewaktu sang tuan butuh pelayanan seksual sang Nyai tidak bisa menolak. Setelah sang tuan bosan, Nyai bisa saja 
dikembalikan ke rumah mereka tanpa ikatan apapun.

Para perempuan yang menjadi Nyai Kebanyakan terbujuk rayuan dan ingin hidup enak seperti perempuan Belanda. Namun tidak semua Nyai dengan sukarela menjadi Nyai. Mereka menjadi Nyai karena terpaksa. Biasanya lantaran orangtua perempuan tersebut terjerat hutang. Untuk membayar hutang nya itu terpaksa anak perempuannya dijual. Walaupun hidup dalam keadaan berkecukupan namun tetap saja mereka itu Nyai, yang bisa saja ditinggalkan, atau sang tuan mengambil Nyai baru, tanpa mereka bisa menolak.

Tahun 1850 pemerintah kolonial Belanda mendirikan banyak perkebunan di Pulau Sumatera. Untuk memenuhi tenaga di perkebunan yang dibuka secara besar-besaran dikirimlah tenaga kerja laki-laki dari Jawa Tengah Jawa Timur, Penang, Malaka dan Cina. Jawa Tengah dan Timur dipilih berdasarkan alasan karena mereka gampang diatur, penurut dan rajin, disamping mereka di bawah hukum Hindia Belanda. Tidak seperti yang dari Penang, Malaka, dan Cina karena di bawah hukum Inggris. Para pekerja dari Jawa ini datang dengan perantara para calo yang bekerjasama dengan kepala desa. Kemiskinan merupakan alasan yang kuat untuk mereka menerima tawaran bekerja di perkebunan. Mereka adalah makanan empuk para pemilik perkebunan. Karena tidak bisa membaca dan menulis, mereka bekerja tidak sesuai dengan kontrak yang ditandatangani.

Umumnya tenaga kerja diperkebunan adalah itu adalah kaum laki-laki. Para pemilik perkebunan kwatir terjadi kekacauan akibat tidak tersalurnya hasrat seksual mereka.
Lantaran itu didatang para perempuan dari Jepang dan Jawa. Para pekerja perempuan ini mendapat perlakuan tidak baik dari Admistratur yang biasanya orang Belanda. Selain administratur para perempuan ini juga mendapat perlakukan yang tidak baik dari para Mandor yang kebanyakan beretnis Cina. Jika Administratur dan Mandor menginginkan buruh perempuan yang cantik tersebut harus melayaninya, maka mereka biasa akan diberikan sebuah tanda, untuk memudahkan membawanya kerumah atau ke barak . Perempuan yang diberi tanda ini tidak boleh menolak apa yang diinginkan .oelh administratur atau mandor, jika menolak kemungkinan akan mendapat perlakukuan lebih kejam lagi, jika akan lari pasti tertangkap. Buruh perempuan tersebut harus melakukan tugasnya ini, tidak hanya berlaku bagi pada buruh perempuan yang lajang saja, tapi juga kepada perempuan yang sudah bersuami. Bagi perempuan yang bersuami, suami mereka tidak mempunyai kekuatan apapun untuk menolak karena biasanya para pekerja di perkebunan ini akan dikondisikan punya ketergantungan biasanya dengan cara memberikan pinjaman dengan bunga dan dipotong dengan upah kerja, sementara pinjaman itu mereka gunakan untuk bermain judi, hal ini seringkali menimbulkan masalah dalam perkebunan.

Di perkebunan terjadi praktek pelacuran secara terselubung. Atau hidup bersama tanpa pernikahan resmi. Perempuan diperjualbelikan sesuai dengan kecantikan dan kesigapannya melayani langganan, tanpa menikmati hasil jerih payahnya. Para mandor yang menguasai merekalah yang menikmati hasil itu. Mereka tidak punya 
keberanian untuk keluar dari kondisi tersebut, lantaran begitu kuatnya kekuasan para mandor yang dipercaya oleh pemilik perkebunan. Jika mereka lari dari perkebunan dan tertangkap, maka mereka akan lebih disiksa lagi. Untuk kasus perempuan di perkebunan modus operandinya tidak jauh berbeda sampai saat ini. Tawaran bekerja di tempat yang baik, atau karena terjerat hutang, yang pada akhirnya dijadikan perempuan simpanan atau yang bernasib lebih buruk diperdagangan .

Pendudukan Jepang di Indonesia membuat rakyat Indonesia lebih menderita. Jepang mempunyai peraturan tersendiri untuk para tentara yang datang ke negara jajahannya. Praktek portitusi merupakan hal yang dilegalkan oleh pemerintahan Jepang di negara jajahan. Walau pun legal, namun yang terjadi adalah pemaksaan. Selain perempuan dari Indonesia Jepang juga mendatangkan perempuan dari Korea dan Cina. Banyak perempuan Indonesia yang menjadi korban dengan janji-janji muluk yang diberikan Jepang. Banyak kaum perempuan Indonesia yang menjadi penghibur atau pelacur yang menghibur prajurit Jepang di Saigon, setelah Jepang menjanjikan akan dipekerjakan di palangmerah (Capt.R.P.Soeyono). Tempat pelacuran yang didirikan Jepang tidak hanya di Indonesia. Di Singapura, Taiwan, Sachalin, Birma, Pilipina, Mansuria, dan Cina juga didirikan rumah pelacuran. Semuanya untuk memenuhi kebutuhan prajurit Jepang

Pendudukan Jepang menyisakan penderitaan, tidak saja bagi perempuan Indonesia tetapi juga para perempuan Eropa. Para perempuan tidak bisa menolak apabila prajurit Jepang menginginkannya dirinya . Jika mereka menolak bisa saja seluruh keluarganya dibantai. Banyak perempuan diperkosa dan kemudian dibunuh karena mereka menolak keinginan serdadu Jepangj Kisah para jugun ianfu (perempuan korban perkosaan) yang sangat memilukan merupakan bukti kekejaman tentara Jepang. Jika bangsa Korea tidak dapat memaafkan perlakuan penjajahan Jepang dapat dimaklumi karena lebih 20.000 perempuan Korea dijadikan pelacur sejak 1941 harus melayani tentara Jepang di berbagai negara Asia.

Setelah Perang Dunia ke 2, Jepang menjadi negara yang makmur dan kuat. Kemakmuran Jepang menguntungkan kaum laki-laki. Kondisi laiki-laki Jepang tidak berbeda dengan masa perang dunia ke 2. Apabila masa penjajahan Jepang melakukannya dengan secara paksa membawa para perempuan ketempat-tempat hiburan tentara Jepang, pasca perang dunia ke 2 banyak perempuan dari negara-negara Asia seperti Thailand, Pilipina dikirim ke Jepang dengan sukarela untuk mendapatkan imbalan yang besar. Jepang terkenal sebagai pasar terbesar perdagangan perempuan. Dunia wisata kemudian menjadi bungkus dari perdagangan perempuan. Dunia pelacuran di Jepang sangat menguntungkan pemerintah. Dari hasil pelacuran Jepang memperoleh dana sama dengan yang dikeluarkan untuk anggaran pertahanan. (Mayori Matsui, 2002 )

\section{Perdagangan Perempuan di Zaman Moderen}

Pada saat ini perdagangan dan pelacuran merupakan bagian dari industri raksasa global, namun untuk negara -negara Asia termasuk Indonesia perdagangan dan pelacuran ini dibungkus dengan kepentingan 
bisnis. Perdagangan, perempuan dan pelacuran merupakan perdagangan yang sangat luas yang dikelola oleh jaringan bisnis raksasa. Dalam prinsip ekonomi pasar segala sesuatu dapat dijual termasukl seksualitas perempuan, kondisi seperti ini bisa dikatakan sebagai bentuk perbudakan moderen.

Pada dasarnya perdagangan perempuan terkait dengan kondisi negara, seperti politik negara; perlindungan negara terhadap perempuan; budaya masayarakat, dan ekonomi negara. Perempuan yang menjadi pelacur umumnya datang dari desa-desa yang miskin dan daerah pertanian. Mereka yang kurang mempunyai pengetahuan yang memadai untuk hidup di kota besar. Karena miskin secara ekonomis maka miskin pula ketrampilan dan pengetahuannya. Inilah yang membuat perempuan tersebut mudah sekali untuk dimanfaatkan.

Kasus perdagangan perempuan yang terbungkus perkawinan (penelitian yang dibukukan, Andy Yentriyani 2004 ) bercerita tentang perempuan miskin di Propinsi Pontianak Kabupaten Sambas yang menikah dengan para pria miskin atau laki-laki tanpa masa depan di Taiwan. Untuk mencari pasangan istri ini para laki-laki tersebut menggunakan jasa perantara yang akan mendapat imbalan cukup memadai. Perantara tidak bertanggungjawab andaikata sang perempuan mengalami perlakuan yang tidak baik dari keluarga suaminya di kemudian hari setelah menikah. Dari tahun 19872001 terjadi 20.000 perkawinan antara perempuan muda di Kalimantan Barat dengan laki-laki Taiwan, Walaupun mereka menikah secara resmi namun banyak diantara mereka yang kemudian hanya dijadikan pembantu dan bekerja secara paksa.

Bosan dengan kemiskinan juga menjadi salah satu penyebab,para perempuan keturunan China Benteng yang tinggal di Kampung Belakang kelurahan Kamal Jakarta Barat menerima pinangan laki-laki yang berasal dari Taiwan dengan kisaran usia 30 sampai 50 tahun. Harapan mereka menjadi istri laki-laki yang berasal Taiwan tersebut akan mengubah kehidupan mereka kearah yang lebih baik.menurut peneliti Taiwan Li Ju Chen saat ini ada 26.00o perempuan Indonesia yang di Taiwan (Kompas ) Tidak semua perempuan yang menikah dengan laki-laki Taiwan ini mendapatkan apa yang mereka impikan, biasanya setelah sampai di Taiwan kadangkala mereka hanya dijadikan pembantu atau atau mendapat suami pemabuk dan bahkan ada yang diperdagangan menjadi pemuas nafsu laki-laki.

Beberapa kasus perdagangan perempuan Indonesia dari kurun waktu 4 (empat) tahun dari 2004 sampai 2008 yang terjadi di Indonesia, data diperoleh dari Litbang Kompas, 25 April terungkap kasus perdagangan perempuan di kota Semarang . 25 Juni 2004 terungkap kasus perdagangan perempuan di Kalimantan Barat yang menimpa 3 orang perempuan yang dijanjikan bekerja di Malaysia sebagai buruh pabrik, namun akhirnya ketiga perempuan ini dipekerjakan sebagai pekerja seks komersial di Kualalumpur, ketiganya berasal dari Pontianak . Pada tanggal 25 Juli 2004 tujuh (7) perempuan berasal dari JawaTengah dan Jawa Barat yang akan dipekerjakan sebagai pekerja seks komersial diselamatkan dari Pekanbaru. 7 November 2005 Polda Metrojaya 
menangkap seorang oknum yang akan menjual seorang perempuan ke Sarawak sebagai pekerja seks komersial. Tanggal 24 Februari 2006 Polda Sumatera Utara berhasil membongkar sindikat perdagangan manusia yang berskala internasional yang beroperasi di Indonesia sejak 2003. korban mereka adalah tenaga kerja Indonesia yang tertangkap di Malaysia karena tidak memiliki dokumen imigrasi. Bulan Agustus 20067 (tujuh ) gadis berasal dari Banyumas Jawa Tengah dijual ke Medan oleh jaringan perdagangan perempuan, mereka dijanjikan akan dipekerjakan di Kafe, namun kenyataannya mereka dijual kemucikari dengan 3-4 juta perorang. Pada bulan September 2006 hal yang sama juga dialami oleh 14 perempuan yang berasal dari Jawa Barat diperdagangan oleh sindikat perdagangan perempuan ke Pulau Bangka Belitung. Masih pada tahun yang sama bulan Desember juga terungkap perdagangan perempuan dengan berkedok tenaga kerja perempuan yang melibatkan jaringan perdagangan perempuan JakartaPontianak- Malaysia

Bulan Januari tahun 2007, terbongkar pengiriman perempuan ke Papua yang berasal dari Nusa Tenggara Timur sebanyak 327 perempuan dibawah usia 18 tahun, awalnya mereka dijanjikan bekerja sebagai pembantu, namun sesampai di Papua mereka dipekerjakan sebagai pekerja seks komersial. Mei 2007 polisi juga berhasil mengungkap jaringan perdagangan perempuan yang dipaksa bekerja sebagai pekerja seks komersial di Malaysia dengan pura-pura sebagai perusahaan pengerah tenaga kerja. Pada bulan Agustus 2007 dua orang gadis ke polisi bahwa mereka dipaksa menjadi pekerja seks komersial di Sibu,
Serawak , Malaysia dan Entikong dan tidak dibayar awalnya dijanjikan bekerja di kafe. Tanggal 15 Januari 2008 sebanyak 16 perempuan muda dipaksa menjadi pemijat dan pekerja seks komersial di Jakarta, mereka dijanjikan bekerja sebagai pelayan restoran . Tanggal 3 April 2008 tiga gadis remaja juga menjadi korban perdagangan perempuan di kabupaten Kutai Kartanegara Kalimantan Timur. Pada bulan Mei 2008 sejumlah perempuan muda dari Jawa Barat diperdagangan ke Bali. Mereka dijual dengan harga 1 sampai 1,5 perorang untuk bekerja sebagai pekerja seks komersial.

Kasus - kasus perdagangan perempuan di atas itu yang nyata-nyata terbuka bukan yang terselubung. Selubung yang lain yang sangat rentan untuk disalahgunakan biasanya berhubungan dengan paket pariwisata, duta kesenian dan pengiriman tenaga kerja perempuan keluarnegeri. Laporan Konsorsium Pembela Buruh Migran pada tahun 2001 dalam penempatan tenaga kerja Indonesia di luarnegeri sejumlah 74.616 telah menjadi korban perdagangan orang dan jumlah terbanyak dari mereka adalah perempuan, 18 .ooo dari mereka bekerja sebagai pekerja seks komersial. Pada tahun 2008 terungkap pengiriman maha siswi dari salah satu akademi pariwisata di Jakarta untuk training kerja dalam bidang pariwisata, dengan menggunakan visa turis padahal mereka dipekerjakan sebagai pekerja seks komersial. Pengiriman tenaga kerja perempuan secara illegal sebagai pekerja terutama di negara-negara Timur Tengah juga rentan untuk dijadikan jaringan perdagangan perempuan. Sementara yang memiliki paspor tidak kalah rentannya karena paspor yang dimiliki pekerja ini diambil 
oleh majikan atau calo yang mengirim mereka. Tina adalah seorang perempuan Indonesia bekerja di Arab Saudi sebagai pembantu rumahtangga dengan ijazah SMA. Jam kerja Tina mulai 6.oo pagi dan tidak mendapat hari libur dalam perjalanan kerjanya majikan laki-laki menikah lagi dan Tina diharuskan bekerja untuk 2 istri majikannya, kerja yang berat tanpa istirahat dan ditambah pemukulan yang dilakukan oleh istri tua majikannya , karena tidak tahan lagi ia melawan dan memutuskan untuk berhenti bekerja, namun Tina tidak bisa kembali ke Indonesia karena paspor yang dimilikinya ditahan oleh majikannya maka Tina harus menahan penderitaan tersebut selama 2 tahun sesuai dengan kontraknya. Setelah 2 tahun ia kembali ke Indonesia di bandara calo yang merekrut untuk bekerja di Arab Saudi telah menunggu dan minta secara paksa imbalan sejumlah 150 ribu dan diperkosa pula. Tahun berikutnya Tina mencoba lagi untuk bekerja di Hongkong mengikuti kakaknya yang sudah terlebih dahulu bekarja di sana, Tina secar diam-diam sempat membaca kontrak kerja. Di kontrak kerja tertulis gaji yang akan diterimanya sejumlah 2.800 dollar Hongkong dan mendapat libur satu hari, namun setelah ia bekerja yang ia terima hanya 1000 dollar Hongkong. Ia protes ke agen perekrutan, akibatnya ia diancam akan dipulang tanpa gaji ke Indonesia, selain itu ia juga tidak diberikan hak untuk libur. Suatu hari Tina bertemu dengan pekerja asal Pilipina yang kemudian menjadi motivatornya pekerja Pilipina ini memberitahukan tentang hak-hak yang dimiliki Tina sebagai pekerja rumahtangga di Hongkong. Setelah ia tidak memperoleh hak-hak yang dimilikinya iapun pergi dari majikannya dan pergi ke Asiaan Migran Center, dari sinilah Tina mulai memperjuangkan hak-haknya lewat pengadilan, peristwa ini terjadi 1994 ,namun sampai tahun 2008 nasib pekerja perempuan Indonesia yang bekerja sebagai pembantu rumahtangga Di Timurtengah belum banyak berubah. Masih banyak pekerja perempuan Indonesia yang terpaksa melayani nafsu seksual para majikannya dan mendapat perlakuan tidak manusiawi. Belum ada data yang bisa mengungkapkan berapa ,banyak bayi yang dilahirkan dengan bapak yang berasal dari negara Timur Tengah.

Sampai saat ini Indonesia masih mendapat nilai buruk dalam upaya menangani kasus -kasus perdagangan perempuan dan anak. Data tentang perdagangan perempuan ini memang tidak mudah didapat, sehingga perkiraan angka tentang perdagangan perempuan sebenarnya lebih besar dari angka yang terungkap.Jumlah perempuan dan anak yang diperdagangkan diperkirakan 700 sampai 1 juta orang (Global Against Child Labour 2002 )

Menurut Elizabeth Dunlap manajer Program IOM Indonesia ,perdagangan manusia periode Maret 2005 sampai Januari 2008 tercatat 3.042 orang, yang terdiri dari bayi perempuan 5 orang, anak perempuan 651 orang, anak-laki-laki 134 orang, perempuan dewasa 2.048 orang, lakilaki dewasa 206 (Kompas ) Daerah kantong berasal dari Kalbar, Jabar, Jatim, Jateng, Sulut, lampung, NTT, Sumsel, Banten, Sulsel, DKI Jakarta dan daerah Indonesia lainnya.

Sementara daerah yang menjadi tujuan perdagangan perempuan ini dapat dibagi menjadi dua kategori dalam dan luar negeri. Untuk dalam negeri 
kantong perdagangan perempuan Batam, Riau, Bangka Belitung, Manado, Papua, Yogyakarta, DKI Jakarta. Untuk pasaraan luar negeri negara tujuan perdagangan perempuan Taiwan, Singapura, Hongkong, Korea, Jepang, Malaysia, Brunai, Australia, Arab Saudi, Uni Emirat Arab, Qatar, Bahrain, Kuwait, Yodania, Mesir, Palestina, negara-negara di Eropa, dan Amerika Serikat. Selain menjadi tempat transaksi perdagangan perempuan negara Indonesia juga menjadi negara transit perdagangan perempuan dari negaranegara seperti China, Ukraina, Belanda, Venuzuela , Spanyol,Thailand, namun jumlah mereka relatif kecil dibandingkan dengan perempuan Indonesia yang diperdagangankan

Faktor kemiskinan merupakan faktor yang sangat dominan dalam kasus perdagangan perempuan. Budaya masyarakat yang patriachat, juga sama yaitu setali tiga uang dengan faktor kemiskinan. Untuk mengakhiri perdagangan perempuan dengan berbagai bungkus ini adalah peran pemerintah dalam politik ekonomi. Walau seberapa banyak imbauan, dan seberapa banyak usaha, namun jika tidak dibarengi dengan kesempatan dan perubahan pola pikir masyarakat tentang keberadaan perempuan, maka perdagangan perempuan akan tetap ada.

\section{Daftar Pustaka}

Alison.J.Murray. 1994. Pedagang Jalanan dan Pelacur Jakarta, LP3ES,.Jakarta

Andy Tentriyeni. 2004. Politik Perdagangan Perempuan, Galang Perss Yogyakarta,

I .Wibowo.ed. 2000. Harga Yang Harus Dibayar,Sketsa Pergulatan Etnis Cina di Indonesia. Gramedia Pustaka Utama. Jakarta

lYayori Matsui. 2002 Perempuan Asia

.Yayasa Obor Indonesia. Jakarta

Katrin Bandel.2006. Sastra Perempuan Seks.Jalasutra ,Yogyakarta

R.P Suyono.2005. Seks dan Kekerasan Pada Masa Kolonial,Penelusuran Kepustakaan Sejarah.Grasindo Jakarta

Sulistyowati Irianto,Lim Sing Meij,Firliana Purwanti,Luki Widiastuti.2005 Perdagangan Perempuan Dalam Jaringan Pengedaran Narkotika.Yayasan Obor Indonesia.Jakarta 